\title{
Exogenous glucagon-like peptide 1 reduces contractions in human colon circular muscle
}

\author{
Antonella Amato, Sara Baldassano, Rosa Liotta', Rosa Serio and Flavia Mulè \\ Laboratorio di Fisiologia Generale, Dipartimento di Scienze e Tecnologie Biologiche Chimiche e Farmaceutiche \\ (STEBICEF), Università di Palermo, Viale delle Scienze, 90128 Palermo, Italy \\ ${ }^{1}$ Mediterranean Institute for Transplantation and Advanced Specialized Therapies (ISMETT), Palermo, Italy
}

Correspondence should be addressed to $F$ Mulè

Email

flavia.mule@unipa.it

\begin{abstract}
Glucagon-like peptide 1 (GLP1) is a naturally occurring peptide secreted by intestinal L-cells. Though its primary function is to serve as an incretin, GLP1 reduces gastrointestinal motility. However, only a handful of animal studies have specifically evaluated the influence of GLP1 on colonic motility. Consequently, the aims of this study were to investigate the effects induced by exogenous GLP1, to analyze the mechanism of action, and to verify the presence of GLP1 receptors (GLP1Rs) in human colon circular muscular strips. Organ bath technique, RT-PCR, western blotting, and immunofluorescence were used. In human colon, exogenous GLP1 reduced, in a concentration-dependent manner, the amplitude of the spontaneous contractions without affecting the frequency and the resting basal tone. This inhibitory effect was significantly reduced by exendin (9-39), a GLP1R antagonist, which per se significantly increased the spontaneous mechanical activity. Moreover, it was abolished by tetrodotoxin, a neural blocker, or $N_{\omega}$-nitro-L-arginine - a blocker of neuronal nitric oxide synthase (nNOS). The biomolecular analysis revealed a genic and protein expression of the GLP1R in the human colon. The double-labeling experiments with anti-neurofilament or anti-nNOS showed, for the first time, that immunoreactivity for the GLP1R was expressed in nitrergic neurons of the myenteric plexus. In conclusion, the results of this study suggest that GLP1R is expressed in the human colon and, once activated by exogenous GLP1, mediates an inhibitory effect on large intestine motility through NO neural release.
\end{abstract}

Key Words

- GLP-1 receptor expression

- intestinal peptides

- colonic motility

- nitric oxide

\section{Introduction}

Glucagon-like peptide 1 (GLP1), produced by intestinal enteroendocrine L-cells in response to the ingestion of nutrients (Schirra et al. 1996), is highly insulinotropic and an inhibitor of gastrointestinal motility, effects that function in concert to limit postprandial glycemic excursion (Kreymann et al. 1987, Bozkurt et al. 2002, Drucker 2005, Schirra et al. 2006). The experimental studies in humans and rodents have shown that GLP1 is one of the principal mediators of the ileal brake (Giralt \&
Vergara 1999), slows gastric emptying, and reduces gastrointestinal motility (Imeryüz et al. 1997, Tolessa et al. 1998b, Näslund et al. 2001, 2002, Delgado-Aros et al. 2002, Miki et al. 2005, Shirra et al. 2006, Amato et al. 2010, Rotondo et al. 2011). The mechanism through which GLP1 mediates inhibition of gastrointestinal motility has not been fully established, and likely involves the activation of vagal nerve (Imeryüz et al. 1997, Wettergren et al. 1998) and direct action on the gut wall

Published by Bioscientifica Ltd 
(Amato et al. 2010, Rotondo et al. 2011). In fact, previous studies have shown that the GLP1 receptor (GLP1R) is expressed in the CNS (Göke et al. 1995) and in the nodose ganglion (Nakagawa et al. 2004), and that exogenous GLP1 can activate vagal afferents (Bucinskaite et al. 2009). More recent evidence has suggested that the activation of enteric neurons mediates GLP1 inhibitory effects by nitric oxide (NO) release (Amato et al. 2010, Rotondo et al. 2011). Actually, GLP1R expression has been found in the enteric neurons of the small and large intestine in different species, including humans (Amato et al. 2010, Baldassano et al. 2012, Mamdouh et al. 2013, Richards et al. 2013).

The GLP1 effects on the stomach and small intestinal motility have been investigated, although the action on lower gut motility is less clear (Marathe et al. 2011). Few studies have analyzed the role of GLP1 in the regulation of colonic contractility, and the results remain controversial because both GLP1 stimulatory (Gülpinar et al. 2000, Ayachi et al. 2005) and inhibitory (Byrne et al. 2001, Amato et al. 2010) effects have been described. Interestingly, constipation has been reported among the side effects in treatment with liraglutide, a human GLP1R agonist, successfully used for the treatment of type 2 diabetes mellitus (Seino et al. 2010, Jeong \& Yoo 2011).

This study was undertaken to examine the possible presence of the GLP1R in the human colon, to analyze the effects of GLP1 on spontaneous mechanical activity, and to determine the GLP1's mechanism of action.

\section{Subjects and methods}

\section{Human tissue excision and preparation}

Specimens of human colon $(n=18)$ were obtained from patients (aged $40-88$ years, $35 \%$ females) with no symptoms of major clinical motility disorders, and who underwent surgery for neoplastic conditions at the Mediterranean Institute for Transplantation and Advanced Specialized Therapies (ISMETT), Palermo, Italy. The experimental protocol was approved by the Institutional Ethics Committee and written informed consent was obtained from all individuals before surgery. Samples consisted of whole wall sections of the colon from a macroscopically normal region taken at a distance of at least $5 \mathrm{~cm}$ from any visible lesion. For the mechanical experiments, the colonic specimens $(n=15$; ten men and five women, aged $40-88$ years) were immediately placed in preoxygenated Krebs solution in a dissection dish in order to remove the mucosal layer, and stored overnight at $4{ }^{\circ} \mathrm{C}$. Other samples $(n=3$; two men and one woman, aged
53-79 years) were frozen and stored at $-80^{\circ} \mathrm{C}$ for subsequent GLP1R expression analysis (RT-PCR and western blot) or fixed in cold $4 \%$ paraformaldehyde, diluted in PBS for immunohistochemistry $(n=3)$.

\section{Functional experiments}

Following the overnight storage, the circular muscle strips ( $4 \mathrm{~mm}$ wide by $10 \mathrm{~mm}$ long) were suspended in a fourchannel organ bath containing $8 \mathrm{ml}$ of heated $\left(37^{\circ} \mathrm{C}\right)$ and oxygenated $\left(95 \% \mathrm{O}_{2}\right.$ and $\left.5 \% \mathrm{CO}_{2}\right)$ Krebs solution with the following composition (mM): $\mathrm{NaCl} 119, \mathrm{KCl} 4.5, \mathrm{MgSO}_{4}$ 2.5, $\mathrm{NaHCO}_{3} 25, \mathrm{KH}_{2} \mathrm{PO}_{4} 1.2, \mathrm{CaCl}_{2} 2.5$, and glucose 11.1. One end of each strip was tied to organ holders, while the other end was secured with a silk thread to an isometric force transducer (FORT 25, Ugo Basile, Biological Research Apparatus, Comerio, VA, Italy). Mechanical activity was digitized on an analog-to-digital converter, visualized, recorded, and analyzed on a personal computer using the PowerLab/400 System (Ugo Basile). A tension of $1 \mathrm{~g}$ was applied, and the tissue was allowed to equilibrate for $1 \mathrm{~h}$. During this period, the strips developed spontaneous phasic contractions.

After the equilibration period, the effects induced by non-cumulative concentrations of GLP1 $(1 \mathrm{nM}-1 \mu \mathrm{M})$ on the spontaneous mechanical activity were examined. The peptide was added to the bath at increasing concentrations in volumes of $80 \mu \mathrm{l}$, and left in contact with the tissue for $7 \mathrm{~min}$. The response to GLP1 was also tested in the presence of exendin (9-39) (100 nM), a GLP1R antagonist; tetrodotoxin (TTX; $1 \mu \mathrm{M}$ ), a voltage-dependent $\mathrm{Na}^{+}$-channel blocker; and $N_{\omega}$-nitro-L-arginine (L-NNA; $300 \mu \mathrm{M}$ ), an inhibitor of neuronal NO synthase (nNOS).

\section{GLP1R expression analysis and immunofluorescence}

Total RNA from human colon specimens was extracted with the PureLink RNA Mini Kit (Invitrogen) according to manufacturer's instructions. After quantification by spectrophotometry, $1 \mu \mathrm{g}$ of total RNA was reverse transcribed with the High-Capacity c-DNA RT Kit (Applied Biosystems). The GLP1R and $\beta$-actin were amplified using $5 \mu$ of cDNA (30 ng total RNA equivalents) per reaction. The oligonucleotide primers for human GLP1R and $\beta$-actin were as follows: F, $5^{\prime}$-tctctgctctggttatcgcctc- $3^{\prime}$ and $\mathrm{R}, 5^{\prime}$-agataagaccgagaaggccagc- $3^{\prime}$ to generate a $317 \mathrm{bp}$ product from human GLP1R; and F, 5'-tggcaccacaccttctacaatgagc- $3^{\prime}$ and $\mathrm{R}, 5^{\prime}$-gcacagcttctccttaatgtcacgc- $3^{\prime}$ to generate a $396 \mathrm{bp}$ product from human $\beta$-actin, as described previously (Suen et al. 2008). The primers were

Published by Bioscientifica Ltd 
verified on gene sequence by public databases (Homo sapiens GLP1R mRNA GenBank accession no.: NM_002062.3 and Homo sapiens $\beta$-actin mRNA GenBank accession no.: NM_001101.3).

The thermal cycle profile employed a $5 \mathrm{~min}$ denaturing step at $94{ }^{\circ} \mathrm{C}$ followed by 40 cycles at $95^{\circ} \mathrm{C}$ for $15 \mathrm{~s}, 60^{\circ} \mathrm{C}$ for $60 \mathrm{~s}$, and $72^{\circ} \mathrm{C}$ for $30 \mathrm{~s}$, and a final extension step of $10 \mathrm{~min}$ at $72^{\circ} \mathrm{C}$. The amplimers were separated on a $1 \%$ agarose gel containing $0.5 \mu \mathrm{g} / \mathrm{ml}$ of ethidium bromide for visualization, and the gel was scanned under u.v. light. Hep-G2 cell line (purchased from ATCC, Manassas, VA, USA) was used as positive control (Gupta et al. 2010, Svegliati-Baroni et al. 2011).

For western blotting, $30 \mathrm{mg}$ of tissue from the colon was incubated on ice in RIPA buffer $(50 \mathrm{mM}$ Tris- $\mathrm{HCl}, \mathrm{pH}$ 7.4; $150 \mathrm{mM} \mathrm{NaCl}, 1 \%$ Nonidet P-40) containing protease inhibitors (2 $\mathrm{mM}$ phenylmethylsulphonyl fluoride, $\mathrm{NaVO}_{3}$ ) for $1 \mathrm{~h}$. Subsequently, it was centrifuged at $4{ }^{\circ} \mathrm{C}$ for $15 \mathrm{~min}$ at $13200 \mathrm{~g}$, and the supernatant was isolated. Protein concentration was measured by the Bio-Rad Protein Assay (Bio-Rad Laboratories). Proteins $(50 \mu \mathrm{g})$ were separated by $10 \%$ SDS-PAGE containing $0.1 \%$ SDS and transferred to Hybond-C nitrocellulose membranes (Amersham Life Science) by electroblotting. Loading and transfer conditions were assessed by staining of the gel with Ponceau red. The relative migration position of the target protein was detected with a co-electrophoresed prestained molecular weight protein ladder (Invitrogen). The membranes were sequentially incubated overnight with antibodies to GLP1R (Santa Cruz Biotechnology; diluted 1:100), or $\beta$-actin (Sigma-Aldrich; diluted 1:200) applied as a loading control, and then incubated with a goat anti-rabbit immunoglobulin G (IgG) secondary antibody conjugated to HRP (diluted 1:2000), recommended for GLP1R detection (Santa Cruz Biotechnology), or sheep anti-mouse IgG-HRP (diluted $1: 10000)$, recommended for $\beta$-actin detection (Amersham Pharmacia). The target proteins were detected by ECL (Pierce, Rockford, IL, USA). Once more, Hep-G2 cells were used as positive control. Negative controls were created by omitting the primary antibodies. The specificity of GLP1R antibody was previously demonstrated in mouse brain slides (Hamilton \& Hölscher 2009) or in human retinal pigment epithelium cell line (Puddu et al. 2013).

For the immunohistochemical study, primary and secondary antibodies were used, as listed in Table 1 . The specimens $(n=3)$ were included in Killik cryostat embedding medium (Bio-Optica, Milan, Italy) and frozen at $-80^{\circ} \mathrm{C}$. Transverse sections, $10 \mu \mathrm{m}$ thick, were cut, collected on polylysine-coated slides, and fixed in Zamboni's fixative
Table 1 Codes and sources of the primary and secondary antibodies used in the study

\begin{tabular}{|c|c|c|c|c|}
\hline Antigen & Host & Code & Dilution & Source \\
\hline Anti-NF & Mouse & N5264 & 1:100 & Sigma-Aldrich \\
\hline & Rabbit & sc-66911 & & $\begin{array}{l}\text { Santa Cruz } \\
\text { Biotechnology }\end{array}$ \\
\hline nNOS & Mouse & $\begin{array}{c}\text { NOS-3F7- } \\
\text { B11-B5 }\end{array}$ & $1: 100$ & Sigma-Aldrich \\
\hline $\begin{array}{l}\text { Rabbit } \\
\text { lgG }\end{array}$ & $\begin{array}{l}\text { Goat } \\
\text { FTC }\end{array}$ & $111-095-003$ & $1: 100$ & $\begin{array}{l}\text { Jackson Immuno- } \\
\text { research, } \\
\text { Suffolk, UK }\end{array}$ \\
\hline $\begin{array}{l}\text { Mouse } \\
\lg G\end{array}$ & $\begin{array}{l}\text { Goat } \\
\text { Cy3 }\end{array}$ & $115-165-003$ & $1: 500$ & $\begin{array}{l}\text { Jackson Immuno- } \\
\text { research }\end{array}$ \\
\hline
\end{tabular}

Anti-NF, anti-neurofilament; GLP1R, glucagon-like peptide 1 receptor; nNOS, neuronal nitric oxide synthase.

( $4 \%$ formaldehyde plus $0.2 \%$ picric acid in $0.1 \mathrm{M}$ sodium phosphate buffer, $\mathrm{pH}$ 7.0) for $15 \mathrm{~min}$ at room temperature. After fixation, the tissues were washed $(3 \times 10 \mathrm{~min})$ in PBS $(0.9 \% \mathrm{NaCl}$ in $0.1 \mathrm{M}$ sodium phosphate buffer, $\mathrm{pH} 7.0)$ and placed in PBS containing 20\% fetal bovine serum, 5\% BSA, and $0.1 \%$ Triton X-100 (Sigma-Aldrich) for $30 \mathrm{~min}$ at room temperature to minimize nonspecific binding and increase tissue permeability. The tissues were incubated overnight at $4{ }^{\circ} \mathrm{C}$ with primary antibodies for GLP1R or a mixture of primary antibodies for double labeling. After being washed with PBS, the tissues were incubated with a single secondary antibody or a mixture of appropriate secondary antibodies conjugated with fluorescein isothiocyanate or indocarbocyanine (Сy3), at room temperature for $1 \mathrm{~h}$, followed by washing in PBS and mounting with VECTASHIELD (Vector, Burlingame, CA, USA). Negative controls were created by omitting the primary antibodies or substituting it with a no-immune rabbit serum and no labeling was observed (data not shown).

Fluorescence labeling was examined with an Olympus BX 50 fluorescence microscope (Olympus Italy, Milano, Italy). Photomicrographs were acquired with a Nikon DS-U1 Monochrome digital camera and NIS-Elements Software (Nikon Instruments, Melville, NY, USA), stored on disk and analyzed with NIS-Elements. Images were minimally adjusted for brightness and contrast using NIS-Elements. nNOS-immunoreactive (IR)-neurons that expressed GLP1R-IR were counted on three adjacent slices at the distance of $50 \mu \mathrm{m}$ from each other.

\section{Drugs}

The following drugs were used: L-NNA (Sigma-Aldrich), TTX (Alomone Labs, Jerusalem, Israel), GLP1 (7-36) amide, and exendin (9-39) (Tocris Biosciences, Bristol,

Published by Bioscientifica Ltd 
UK). Each compound was prepared as a stock solution in distilled water. The working solutions were prepared fresh on the day of the experiments by diluting the stock solutions in Krebs.

\section{Data and statistical analysis}

The inhibitory response of the circular muscle to GLP1 was taken as the change in percentage from the resting spontaneous activity (e.g. 100\% corresponds to the abolition of spontaneous activity). The mean amplitude of spontaneous contractions was measured before and following the administration of a drug when a new steady state was reached. All data are expressed as mean values \pm S.E.M. The letter $n$ indicates the number of human colonic specimens. The concentration-response curves were fitted to a sigmoidal curve using nonlinear regression (Prism 4.0, GraphPad Software, San Diego, CA, USA). Statistical analysis was done with the Student's t-test or ANOVA, followed by the Bonferroni's post hoc test when appropriate. A probability value of $<0.05$ was regarded as significant.

\section{Results}

\section{Functional studies}

Circular muscle strips of human colon exhibited spontaneous mechanical activity consisting of phasic contractions at a frequency of $2.7 \pm 0.3$ contractions/min $(n=15)$ and an amplitude of $4 \pm 0.5 \mathrm{~g}(n=15)$. GLP1 $(1 \mathrm{nM}-1 \mu \mathrm{M})$ produced a decrease in the mean amplitude of spontaneous contractions without affecting the frequency and the resting basal tone (Fig. 1A). The inhibitory effect was enhanced by increasing the concentration of the peptide and was completely reversible after washout with normal Krebs solution. As shown by the concentration-response curves (Fig. 1B), the response obtained at the maximal tested concentration ( $1 \mu \mathrm{M}$ GLP1) corresponded to $60 \%$ reduction in the amplitude of spontaneous contractions. To assess the specificity of the effect, the preparations were pretreated for $30 \mathrm{~min}$ with exendin (9-39) (100 nM), a GLP1R antagonist, which per se significantly increased the spontaneous mechanical activity $(+41.5 \pm 2.0 \%, n=5$; $P<0.01$ ) (Fig. 1C). Exendin (9-39) markedly reduced the inhibitory effect induced by GLP1 (Fig. 1B). Moreover, the response to GLP1 was abolished by TTX $(1 \mu \mathrm{M})$, a blocker of neural voltage-dependent $\mathrm{Na}^{+}$channels (Fig. 2A), suggesting its neural origin, and by L-NNA $(300 \mu \mathrm{M})$, a blocker of nNOS (Fig. 2B). TTX failed to affect spontaneous contractions, indicating its balanced effect on excitatory and inhibitory nerves, while L-NNA increased the contraction amplitude suggesting that NO exerts a tonic inhibitory action on human circular muscle.

\section{Molecular analysis of GLP1R expression}

In the colonic specimens, RT-PCR revealed the presence of a 317 bp mRNA encoding the GLP1R, with the expression of a $\beta$-actin PCR product (396 bp) as standard. The gene was also expressed in Hep-G2 cell line, used as positive control (Fig. $3 \mathrm{~A})$. Western blot analysis confirmed that the colonic human preparations express GLP1R at the protein level. A single $56-\mathrm{kDa}$ band was detected in human colonic tissue and in Hep-G2 cells used as a positive control (Fig. 3B).

\section{Immunofluorescence}

We used immunohistochemical staining to identify the location of GLP1R in the myenteric plexus area of our human colon tissue samples. Double labeling with antineurofilament (anti-NF) showed that IR for GLP1R is present in the neurons of the myenteric plexus.

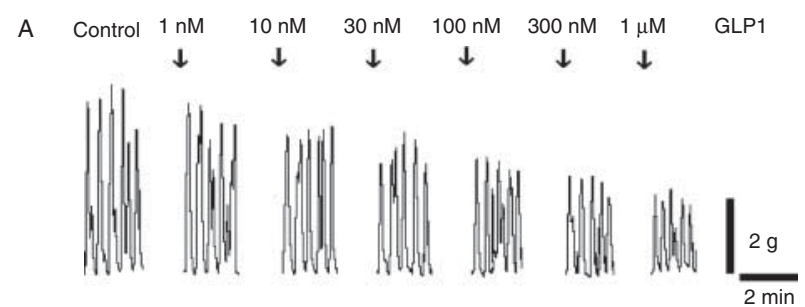

B

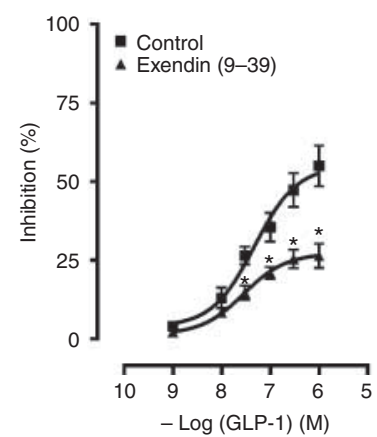

C

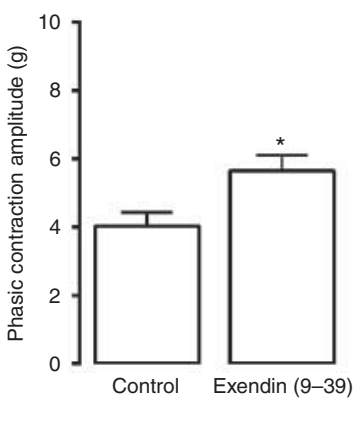

\section{Figure 1}

(A) Typical recordings showing the inhibitory effects of increasing concentrations of GLP1 on spontaneous contractions of human colon circular muscle fiber cells. (B) Concentration-response curves for the inhibitory effects induced by GLP1 before and after treatment of the preparation with exendin (9-39) (100 nM). Data are expressed as the percentage of inhibition of the spontaneous contractions. (C) Effects of exendin (9-39) (100 nM) on spontaneous contraction amplitude. Data are means \pm s.E.M. $(n=5) .{ }^{*} P<0.05$ compared with the respective control conditions.

Published by Bioscientifica Ltd. 

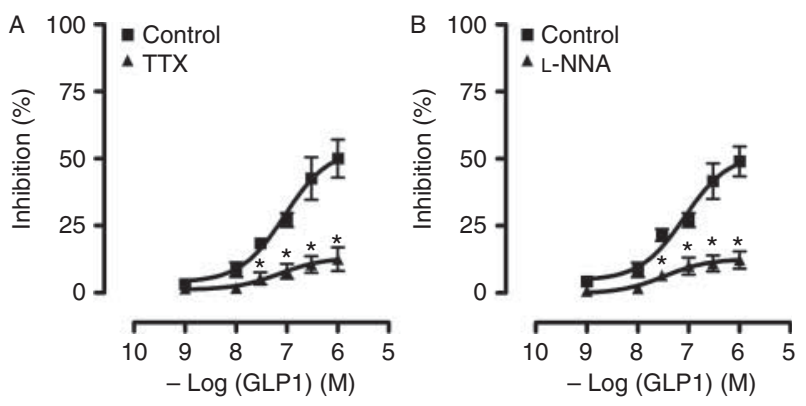

Figure 2

(A) Concentration-response curves for the inhibitory effects induced by GLP1 in the control conditions and in the presence of TTX $(1 \mu \mathrm{M})$.

(B) Concentration-response curves for the inhibitory effects induced by GLP1 in the control conditions and in the presence of L-NNA (300 $\mu \mathrm{M})$. Data are means \pm S.E.M. $(n=5)$ and are expressed as the percentage of inhibition of the spontaneous contraction. ${ }^{*} P<0.05$ compared with the respective control conditions.

Moreover, we found that neurons with IR for $\mathrm{nNOS}$ coexpressed GLP1R-IR (Fig. 4). Among the nNOS-IR neurons, $34.6 \pm 2.5 \%$ co-expressed GLP1R. Muscle cells did not express GLP1R-IR.

\section{Discussion}

This study shows that GLP1R is expressed in the human colon and, once activated by exogenous GLP1, mediates an inhibitory effect on large intestinal motility through NO neural release. In addition to its well-known glucoregulatory effects, GLP1 is able to affect the motor functions of the gastrointestinal tract in different species, including humans (Marathe et al. 2011). In fact, it inhibits gastric emptying, relaxes the antral region of the stomach, and reduces the motility of the upper intestine (Wettergren et al. 1993, Giralt \& Vergara 1999, Miki et al. 2005, Nagell et al. 2006, Schirra et al. 2006, Amato et al. 2010, Rotondo et al. 2011). Despite the clear inhibitory effects exerted by the peptide on the motility of the upper gastrointestinal tract, a potential regulatory effect on large intestine mechanical activity has yet to be clarified. On the other hand, it has been shown that the enteroendocrine cells of the human colon fully process biologically active GLP1 in concentrations similar to that reported for the small intestine, and that are high enough to have a physiological role (Deacon et al. 1995).

Indeed, current knowledge of the GLP1R expression in human tissue is incomplete and based largely on receptor mRNA investigations in whole-organ preparations (Wei \& Moisov 1995, Satoh et al. 2000). The protein has been found in a variety of tissues, including the brain and pancreas (Baggio \& Drucker 2007, Tornehave et al. 2008), hepatic cells (Gupta et al. 2010), adipocytes (Vendrell et al. 2011), and gastric mucosa (Broide et al. 2013). Concerning the bowel, low levels of GLP1R protein expression have been found in duodenal Brunner's glands and the myenteric plexus of the human gut, including the colon, by autoradiography (Körner et al. 2007), but the possible functions mediated by GLP1R in these regions remain purely hypothetic.

This study provides further evidence of the presence of GLP1R in the human distal colon, supported by conventional analysis (RT-PCR, immunoblot). Furthermore, the activation of the receptor by exogenous GLP1 induces a reduction of the spontaneous mechanical activity of human circular smooth muscle, suggesting, for the first time, an inhibitory role of GLP1 on human colonic motility. This mechanism is consonant with the GLP1 capacity of delaying gastrointestinal transit not only in humans but also in rodents (Tolessa et al. 1998a,b, Näslund et al. 2001, Miki et al. 2005, Schirra et al. 2009, Hellström 2011). Moreover, our results could provide a mechanistic explanation for the observations that GLP1-secreting tumors are associated with severe constipation and delayed colonic transit (Byrne et al. 2001,

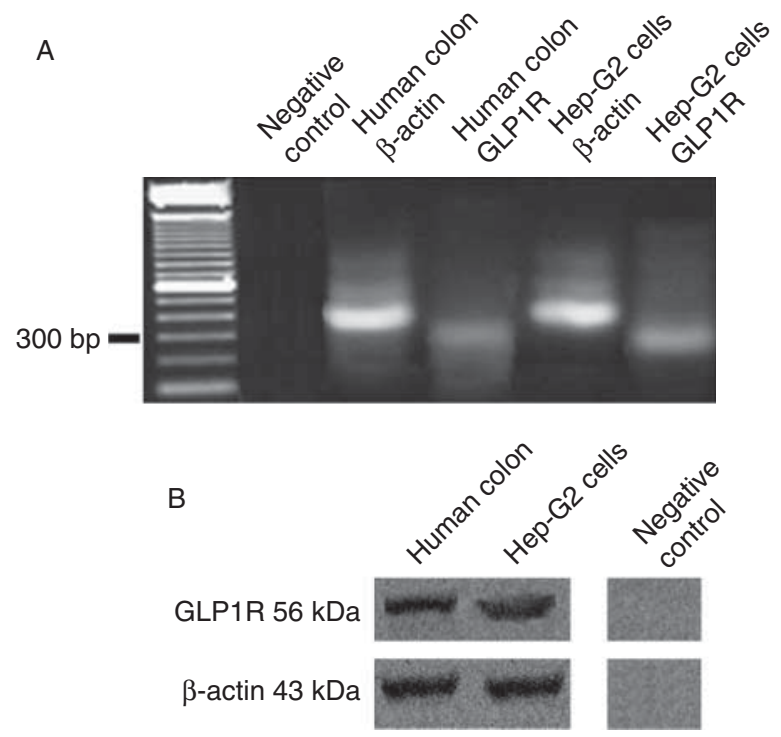

Figure 3

(A) Detection of GLP1R mRNA expression in human colon tissue samples by RT-PCR. A product of 317 bp corresponding to GLP1R was detected in human colon tissue samples and in Hep-G2 cells (positive control). The expression of $\beta$-actin (396 bp) was used as a common reference PCR product. Negative control was obtained without addition of CDNA. (B) Immunoblots of whole homogenates from human colon and Hep-G2 cells (positive control) showing the expression of GLP1R and $\beta$-actin (loading control). Negative control was obtained by omitting the primary antibody.

Published by Bioscientifica Ltd. 

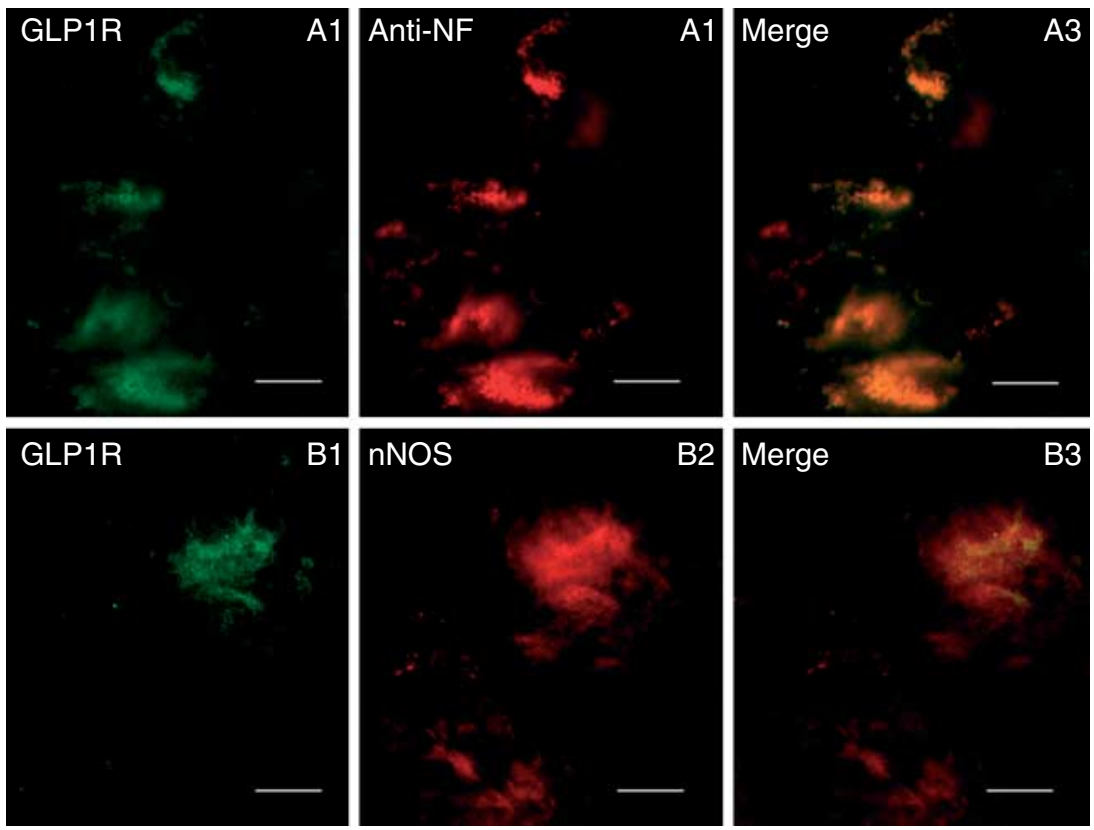

Figure 4

Expression of immunoreactivity (IR) for the GLP1 receptor (GLP1R) in the myenteric plexus area of the human colon tissue sample. (A1, A2, and A3). Coexpression of GLP1R-IR with anti-NF-IR. (B1, B2, and B3) Coexpression of GLP1R-IR with nNOS-IR. Scale bars, $20 \mu \mathrm{m}$.

Brubaker et al. 2002), and for the constipation observed in prolonged treatment with liraglutide (Jeong \& Yoo 2011).

Our finding seem in contrast with previous findings that showed weak contractions in response to GLP1 in isolated circular smooth muscle cells from the human colon, which are likely due to an increase in the availability of glucose energy (Ayachi et al. 2005). However, our preparations consisted of full thickness muscular strips, in which different cellular types, including enteric neurons, are present. Then, as discussed below, a GLP1 inhibitory action mediated by the enteric nervous system may lead to a decrease in contractions.

The inhibitory responses induced by GLP1 were significantly antagonized by exendin (9-39), a specific GLP1R antagonist (Schirra et al. 1998), indicating the specificity of the observed effect. Moreover, it is worth noting that exendin (9-39) per se increased the spontaneous contractions of circular colonic smooth muscle. This observation could be interpreted as suggested that exendin (9-39) is an inverse agonist of the GLP1R, as reported in other experimental studies (Serre et al. 1998, De León et al. 2008, Calabria et al. 2012). We retain that it is an unlikely hypothesis that exendin (9-39) can disclose a tonic action of endogenous GLP1, as suggested in previous in vivo studies (Schirra et al. 2006, 2009), because we used mucosa-free muscular strips in vitro, so our preparations were lacking the primary source of GLP1.
One still open question concerns the relative importance of the local enteric nervous system in mediating the actions of GLP1 in the gastrointestinal tract. Although some GLP1 gastrointestinal motor effects appear to be centrally mediated (Gülpinar et al. 2000), with the involvement of vagal nerves (Imeryüz et al. 1997, Delgado-Aros et al. 2002, 2003, Bucinskaite et al. 2009, Schirra et al. 2009), the hypothesis that GLP1 may act directly on the enteric nervous system has also been advanced (Tolessa et al. 1998a,b, Daniel et al. 2002, Chan et al. 2007, Amato et al. 2010, Rotondo et al. 2011, Mamdouh et al. 2013).

The observation that TTX, a blocker of neural voltagedependent $\mathrm{Na}^{+}$channels, abolishes the inhibitory effects induced by GLP1 suggests that neurons within the intramural plexus are responsible for the action of the peptide in human colon circular muscle strips. Furthermore, the inhibitory effect of GLP1 was also abolished in the presence of L-NNA, a blocker of NO synthesis, suggesting that it is mediated by NO production. Indeed, the involvement of nitrergic neural pathways has been reported in the effects induced by exogenous GLP1 on gastrointestinal motor function in different animal species, including humans (Tolessa et al. 1998b, Näslund et al. 2002, Andrews et al. 2007, Amato et al. 2010, Rotondo et al. 2011).

Our immunofluorescence results showing coexpression of GLP1R and nNOS in myenteric neurons are

Published by Bioscientifica Ltd 
the first report on the presence of GLP1R on the surface of human colon nitrergic neurons, and are consistent with the conclusion that GLP1R activation reduces human colon contractility through neural release of NO.

The concentrations found in our experiments to be effective are higher than the plasmatic level reported in humans (Ørskov et al. 1994), thus our data do not support the idea that GLP1 effects may be mediated via circulating GLP1 in an endocrine manner. Nevertheless, it remains possible that GLP1 acts with a paracrine mechanism near its site of production (colonic enteroendocrine L-cells), reaching concentrations sufficient to activate GLP1R.

In conclusion, in the human colon, GLP1R activation is able to inhibit spontaneous mechanical activity through NO neural production. This action might contribute to delaying intestinal propulsion, thus increasing absorption of water and electrolytes, and triggering constipation.

\section{Declaration of interest}

The authors declare that there is no conflict of interest that could be perceived as prejudicing the impartiality of the research reported.

\section{Funding}

This work was supported by a grant from Ministero dell'Istruzione, dell'Università e della Ricerca, Italy.

\section{Author contribution statement}

A A performed the functional and molecular biology experiments, statistical analysis, and data interpretation; S B carried out the immunohistochemistry experiments; R L participated in the conception of the study, provided samples, and reviewed the manuscript; $R \mathrm{~S}$ participated in the conception of the study and data interpretation; and F M designed the study and wrote the paper.

\section{Acknowledgements}

The authors thank Pietro Tagliareni for his assistance with tissue samples, Prof. Natale Belluardo and Prof. Italia Di Liegro for providing anti-NOS and anti-NF antibodies, respectively, and Dr Gabriella Schiera for her assistance with the fluorescence microscope.

\section{References}

Amato A, Cinci L, Rotondo A, Serio R, Faussone-Pellegrini MS, Vannucchi MG \& Mulè F 2010 Peripheral motor action of glucagon-like peptide-1 through enteric neuronal receptors. Neurogastroenterology and Motility 22 664-672. (doi:10.1111/j.1365-2982.2010.01476.x)

Andrews CN, Bharucha AE, Camilleri M, Low PA, Seide B, Burton D, Baxter K \& Zinsmeister AR 2007 Nitrergic contribution to gastric relaxation induced by glucagon-like peptide-1 (GLP-1) in healthy adults. American Journal of Physiology. Gastrointestinal and Liver Physiology 292 G1359-G1365. (doi:10.1152/ajpgi.00403.2006)

http://joe.endocrinology-journals.org DOI: $10.1530 / \mathrm{JOE}-13-0525$
(C) 2014 Society for Endocrinology Printed in Great Britain
Ayachi SE, Borie F, Magous R, Sasaki K, le Nguyen D, Bali JP, Millat B \& Jarrousse C 2005 Contraction induced by glicentin on smooth muscle cells from the human colon is abolished by exendin (9-39). Neurogastroenterology and Motility 17 302-309. (doi:10.1111/j.13652982.2004.00628.x)

Baggio LL \& Drucker DJ 2007 Biology of incretins: GLP-1 and GIP. Gastroenterology 132 2131-2157. (doi:10.1053/j.gastro.2007.03.054)

Baldassano S, Wang GD, Mulè F \& Wood JD 2012 Glucagon-like peptide-1 modulates neurally evoked mucosal chloride secretion in guinea pig small intestine in vitro. American Journal of Physiology. Gastrointestinal and Liver Physiology 302 G352-G358. (doi:10.1152/ajpgi.00333.2011)

Bozkurt A, Näslund E, Holst JJ \& Hellström PM 2002 GLP-1 and GLP-2 act in concert to inhibit fasted, but not fed, small bowel motility in the rat. Regulatory Peptides 107 129-135. (doi:10.1016/S0167-0115(02)00095-2)

Broide E, Bloch O, Ben-Yehudah G, Cantrell D, Shirin H \& Rapoport MJ 2013 GLP-1 receptor is expressed in human stomach mucosa: analysis of its cellular association and distribution within gastric glands. Journal of Histochemistry and Cytochemistry 61 649-658. (doi:10.1369/ 0022155413497586)

Brubaker PL, Drucker DJ, Asa SL, Swallow C, Redston M \& Greenberg GR 2002 Prolonged gastrointestinal transit in a patient with a glucagonlike peptide (GLP)-1- and -2-producing neuroendocrine tumor. Journal of Clinical Endocrinology and Metabolism 87 3078-3083.

Bucinskaite V, Tolessa T, Pedersen J, Rydqvist B, Zerihun L, Holst JJ \& Hellström PM 2009 Receptor-mediated activation of gastric vagal afferents by glucagon-like peptide-1 in the rat. Neurogastroenterology and Motility 21 978-1078. (doi:10.1111/j.1365-2982.2009.01317.x)

Byrne MM, McGregor GP, Barth P, Rothmund M, Göke B \& Arnold R 2001 Intestinal proliferation and delayed intestinal transit in a patient with a GLP-1-, GLP-2- and PYY-producing neuroendocrine carcinoma Digestion 63 61-68. (doi:10.1159/000051874)

Calabria AC, Li C, Gallagher PR, Stanley CA \& De León DD 2012 GLP-1 receptor antagonist exendin-(9-39) elevates fasting blood glucose levels in congenital hyperinsulinism owing to inactivating mutations in the ATP-sensitive $\mathrm{K}^{+}$channel. Diabetes 61 2585-2591. (doi:10.2337/ db12-0166)

Chan SW, He J, Lin G, Rudd JA \& Yamamoto K 2007 Action of GLP-1 (7-36) amide and exendin- 4 on Suncus murinus (house musk shrew) isolated ileum. European Journal of Pharmacology 566 185-191. (doi:10.1016/ j.ejphar.2007.03.050)

Daniel EE, Anvari M, Fox-Threlkeld JE \& McDonald TJ 2002 Local, exendin(9-39)-insensitive, site of action of GLP-1 in canine ileum. American Journal of Physiology. Gastrointestinal and Liver Physiology $\mathbf{2 8 3}$ G595-G602. (doi:10.1152/ajpgi.00110.2002)

Deacon CF, Johnsen AH \& Holst JJ 1995 Human colon produces fully processed glucagon-like peptide-1 (7-36) amide. FEBS Letters 372 269-272. (doi:10.1016/0014-5793(95)00983-G)

De León DD, Li C, Delson MI, Matschinsky FM, Stanley CA \& Stoffers DA 2008 Exendin-(9-39) corrects fasting hypoglycemia in SUR-1-/ - mice by lowering cAMP in pancreatic $\beta$-cells and inhibiting insulin secretion. Journal of Biological Chemistry 283 25786-25793. (doi:10.1074/ jbc.M804372200)

Delgado-Aros S, Kim DY, Burton DD, Thomforde GM, Stephens D, Brinkmann BH, Vella A \& Camilleri M 2002 Effect of GLP-1 on gastric volume, emptying, maximum volume ingested, and postprandial symptoms in humans. American Journal of Physiology. Gastrointestinal and Liver Physiology 282 G424-31.

Delgado-Aros S, Vella A, Camilleri M, Low PA, Burton DD, Thomforde GM \& Stephens D 2003 Effects of glucagon-like peptide-1 and feeding on gastric volumes in diabetes mellitus with cardio-vagal dysfunction. Neurogastroenterology and Motility 15 435-443. (doi:10.1046) j.1365-2982.2003.00422.x)

Drucker DJ 2005 Biologic actions and therapeutic potential of the proglucagon-derived peptides. Nature Clinical Practice. Endocrinology \& Metabolism 1 22-31. (doi:10.1038/ncpendmet0017) 
Giralt M \& Vergara P 1999 Glucagonlike peptide-1 (GLP-1) participation in ileal brake induced by intraluminal peptones in rat. Digestive Diseases and Sciences 44 322-329. (doi:10.1023/A:1026654417697)

Göke R, Larsen PJ, Mikkelsen JD \& Sheikh SP 1995 Distribution of GLP-1 binding sites in the rat brain: evidence that exendin- 4 is a ligand of brain GLP-1 binding sites. European Journal of Neuroscience 7 2294-3009. (doi:10.1111/j.1460-9568.1995.tb00650.x)

Gülpinar MA, Bozkurt A, Coşkun T, Ulusoy NB \& Yegen BC 2000 Glucagonlike peptide (GLP-1) is involved in the central modulation of fecal output in rats. American Journal of Physiology. Gastrointestinal and Liver Physiology 278 G924-G929.

Gupta NA, Mells J, Dunham RM, Grakoui A, Handy J, Saxena NK \& Anania FA 2010 Glucagon-like peptide-1 receptor is present on human hepatocytes and has a direct role in decreasing hepatic steatosis in vitro by modulating elements of the insulin signaling pathway. Hepatology 51 1584-1592. (doi:10.1002/hep.23569)

Hamilton A \& Hölscher C 2009 Receptors for the incretin glucagon-like peptide-1 are expressed on neurons in the central nervous system. Neuroreport 20 1161-1166. (doi:10.1097/WNR.0b013e32832fbf14)

Hellström PM 2011 GLP-1 playing the role of a gut regulatory compound. Acta Physiologica 201 151-156. (doi:10.1111/j.1748-1716.2010.02150.x)

Imeryüz N, Yeğen BC, Bozkurt A, Coşkun T, Villanueva-Peñacarrillo ML \& Ulusoy NB 1997 Glucagon-like peptide-1 inhibits gastric emptying via vagal afferent-mediated central mechanisms. American Journal of Physiology 273 G920-G927.

Jeong KH \& Yoo BK 2011 The efficacy and safety of liraglutide. International Journal of Clinical Pharmacy 33 740-749. (doi:10.1007/ s11096-011-9552-8)

Körner M, Stöckli M, Waser B \& Reubi JC 2007 GLP-1 receptor expression in human tumors and human normal tissues: potential for in vivo targeting. Journal of Nuclear Medicine 48 736-743. (doi:10.2967/ jnumed.106.038679)

Kreymann B, Williams G, Ghatei MA \& Bloom SR 1987 Glucagon-like peptide-1 7-36: a physiological incretin in man. Lancet 2 1300-1304. (doi:10.1016/S0140-6736(87)91194-9)

Mamdouh HK, Guz Y, Grigorian M \& Teitelman G 2013 Functional activity of murine intestinal mucosal cells is regulated by the glucagon-like peptide-1 receptor. Peptides 48 36-44. (doi:10.1016/ j.peptides.2013.07.022)

Marathe CS, Rayner CK, Jones KL \& Horowitz M 2011 Effects of GLP-1 and incretin-based therapies on gastrointestinal motor function. Experimental Diabetes Research 2011 279530. (doi:10.1155/2011/ 279530)

Miki T, Minami K, Shinozaki H, Matsumura K, Saraya A, Ikeda H, Yamada Y, Holst JJ \& Seino S 2005 Distinct effects of glucose-dependent insulinotropic polypeptide and glucagon-like peptide-1 on insulin secretion and gut motility. Diabetes 54 1056-1063. (doi:10.2337/ diabetes.54.4.1056)

Nagell CF, Wettergren A, Ørskov C \& Holst JJ 2006 Inhibitory effect of GLP-1 on gastric motility persists after vagal deafferentation in pigs. Scandinavian Journal of Gastroenterology 41 667-672. (doi:10.1080/ 00365520500408253)

Nakagawa A, Satake H, Nakabayashi H, Nishizawa M, Furuya K, Nakano S, Kigoshi T, Nakayama K \& Uchida K 2004 Receptor gene expression of glucagon-like peptide-1, but not glucose-dependent insulinotropic polypeptide, in rat nodose ganglion cells. Autonomic Neuroscience 110 36-43. (doi:10.1016/j.autneu.2003.11.001)

Näslund E, Bogefirs J, Gryback P, Bjellerup P, Jacobsson H, Holst JJ \& Hellström PM 2001 GLP-1 inhibits gastric emptying of water but does not influence plasma vasopressin, sodium or osmolarity. Scandinavian Journal of Gastroenterology 2 156-162. (doi:10.1080/ 003655201750065906)

Näslund E, Skogar S, Efendic S \& Hellström PM 2002 Glucagon-like peptide-1 analogue LY315902: effect on intestinal motility and release of insulin and somatostatin. Regulatory Peptides 106 89-95. (doi:10.1016/S0167-0115(02)00054-X)
Ørskov C, Rabenhöj L, Wettergren A, Kofod H \& Holst JJ 1994 Tissue and plasma concentrations of amidated and glycine-extended glucagon-like peptide I in humans. Diabetes 43 535-539. (doi:10.2337/ diab.43.4.535)

Puddu A, Sanguineti R, Montecucco F \& Viviani GL 2013 Retinal pigment epithelial cells express a functional receptor for glucagon-like peptide-1 (GLP-1). Mediators of Inflammation 2013 975032. (doi:10.1155/2013/ 975032)

Richards P, Parker HE, Adriaenssens AE, Hodgson JM, Cork SC, Trapp S, Gribble FM \& Reimann F 2013 Identification and characterization of glucagon-like peptide-1 receptor expressing cells using a new transgenic mouse model. Diabetes [in press]. (doi:10.2337/db13-1440)

Rotondo A, Amato A, Lentini L, Baldassano S \& Mulè F 2011 Glucagon-like peptide-1 relaxes gastric antrum through nitric oxide in mice. Peptides 32 60-64. (doi:10.1016/j.peptides.2010.09.028)

Satoh F, Beak SA, Small CJ, Falzon M, Ghatei MA, Bloom SR \& Smith DM 2000 Characterization of human and rat glucagon-like peptide-1 receptors in the neurointermediate lobe: lack of coupling to either stimulation or inhibition of adenylyl cyclase. Endocrinology 141 1301-1309.

Schirra J, Katschinski M, Weidmann C, Schäfer T, Wank U, Arnold R \& Göke B 1996 Gastric emptying and release of incretin hormones after glucose ingestion in humans. Journal of Clinical Investigation 97 92-103. (doi:10.1172/JCI118411)

Schirra J, Sturm K, Leicht P, Arnold R, Göke B \& Katschinski M 1998 Exendin(9-39)amide is an antagonist of glucagon-like peptide-1(7-36)amide in humans. Journal of Clinical Investigation 101 1421-1430. (doi:10.1172/JCI1349)

Schirra J, Nicolaus M, Roggel R, Katschinski M, Storr M, Woerle HJ \& Göke B 2006 Endogenous glucagon-like peptide 1 controls endocrine pancreatic secretion and antro-pyloro-duodenal motility in humans. Gut 55 243-251. (doi:10.1136/gut.2004.059741)

Schirra J, Nicolaus M, Woerle HJ, Struckmeier C, Katschinski M \& Göke B 2009 GLP-1 regulates gastroduodenal motility involving cholinergic pathways. Neurogastroenterology and Motility 21 609-618. (doi:10.1111/ j.1365-2982.2008.01246.x)

Seino Y, Rasmussen MF, Nishida T \& Kaku K 2010 Efficacy and safety of the once-daily human GLP-1 analogue, liraglutide, vs glibenclamide monotherapy in Japanese patients with type 2 diabetes. Current Medical Research and Opinion 26 1013-1022. (doi:10.1185/ 03007991003672551)

Serre V, Dolci W, Schaerer E, Scrocchi L, Drucker D, Efrat S \& Thorens B 1998 Exendin-(9-39) is an inverse agonist of the murine glucagon-like peptide-1 receptor: implications for basal intracellular cyclic adenosine $3^{\prime}, 5^{\prime}$-monophosphate levels and $\beta$-cell glucose competence. Endocrinology 139 4448-4454.

Suen PM, Zou C, Zhang YA, Lau TK, Chan J, Yao KM \& Leung PS 2008 PDZ-domain containing-2 (PDZD2) is a novel factor that affects the growth and differentiation of human fetal pancreatic progenitor cells. International Journal of Biochemistry \& Cell Biology 40 789-803. (doi:10.1016/j.biocel.2007.10.020)

Svegliati-Baroni G, Saccomanno S, Rychlicki C, Agostinelli L, De Minicis S, Candelaresi C, Faraci G, Pacetti D, Vivarelli M, Nicolini D et al. 2011 Glucagon-like peptide-1 receptor activation stimulates hepatic lipid oxidation and restores hepatic signalling alteration induced by a high-fat diet in nonalcoholic steatohepatitis. Liver International 31 1285-1297. (doi:10.1111/j.1478-3231.2011.02462.x)

Tolessa T, Gutniak M, Holst JJ, Efendic S \& Hellström PM $1998 a$ Glucagonlike peptide- 1 retards gastric emptying and small bowel transit in the rat: effect mediated through central or enteric nervous mechanisms. Digestive Diseases and Sciences 43 2284-2290. (doi:10.1023/ A:1026678925120)

Tolessa T, Gutniak M, Holst JJ, Efendic S \& Hellström PM $1998 b$ Inhibitory effect of glucagon-like peptide-1 on small bowel motility. Fasting but not fed motility inhibited via nitric oxide independently of insulin and somatostatin. Journal of Clinical Investigation 102 764-774. (doi:10.1172/JCI942) 
Tornehave D, Kristensen P, Romer J, Knudsen LB \& Heller RS 2008 Expression of the GLP-1 receptor in mouse, rat and human pancreas. Journal of Histochemistry and Cytochemistry 56 841-851. (doi:10.1369/jhc.2008.951319)

Vendrell J, El Bekay R, Peral B, García-Fuentes E, Megia A, Macias-Gonzalez M, Fernández Real J, Jimenez-Gomez Y, Escoté X, Pachón G et al. 2011 Study of the potential association of adipose tissue GLP-1 receptor with obesity and insulin resistance. Endocrinology $\mathbf{1 5 2}$ 4072-4079. (doi:10.1210/en.2011-1070)

Wei Y \& Moisov S 1995 Tissue-specific expression of the human receptor for glucagon-like peptide-I: brain, heart and pancreatic forms have the same deduced amino acid sequences. FEBS Letters 358 219-224. (doi:10.1016/0014-5793(94)01430-9)

Wettergren A, Schjoldager B, Mortensen PE, Myhre J, Christiansen J \& Holst JJ 1993 Truncated GLP-1 (proglucagon 78-107-amide) inhibits gastric and pancreatic functions in man. Digestive Diseases and Sciences 38 665-673. (doi:10.1007/BF01316798)

Wettergren A, Wøjdemann M \& Holst JJ 1998 Glucagon-like peptide-1 inhibits gastropancreatic function by inhibiting central parasympathetic outflow. American Journal of Physiology. Gastrointestinal and Liver Physiology 275 G984-G992.

Received in final form 10 January 2014

Accepted 15 January 2014

Accepted Preprint published online 17 January 2014
Published by Bioscientifica Ltd. 